\title{
Complete tongue protrusion palsy due to subsequent cryptogenic cortical strokes
}

\author{
Dale Sebire, Louise Rigney, Dennis J Cordato
}

Department of

Neurophysiology, Liverpool Hospital, Liverpool, New South Wales, Australia

\section{Correspondence to} Professor Dennis J Cordato, dennis.cordato@sswahs.nsw. gov.au

Accepted 13 January 2015
CrossMark

To cite: Sebire D, Rigney L,
Cordato DJ. BMJ Case Rep
Published online: [please
include Day Month Year]
doi:10.1136/bcr-2014-
207989

To cite: Sebire D, Rigney L, Cordato DJ. BMJ Case Rep include Day Month Year] 207989

\section{DESCRIPTION}

We describe a 76-year-old right-handed man who presented with acute onset of tongue protrusion palsy without additional neurological deficits or pseudobulbar stigmata. He had previously suffered five strokes. Six months prior to this presentation he had an ischaemic stroke in the right precentral gyrus causing dysarthria with slowed tongue movements. However, he was able to protrude his tongue during that admission. MRI at $24 \mathrm{~h}$ following his new presentation showed acute left precentral gyrus cortical infarction involving the most lateral part of the gyrus corresponding to cortical tongue innervation (figures 1A, B). Extensive stroke risk factor work-up did not reveal the stroke mechanism. The patient was categorised as having cryptogenic strokes. His tongue function completely recovered with full tongue protrusion evident after 5 days. It is possible that small infarct size shortened time to recovery.

Isolated inability to protrude the tongue has rarely been described following acute stroke. ${ }^{12}$ Unilateral precentral gyrus cortical infarction, involving the most lateral part of the gyrus, has been reported to cause isolated contralateral tongue deviation due to disruption of the tongue area of the motor cortex and contralateral innervation of genioglossus (the major muscle responsible for tongue protrusion) as compared with bilateral innervation of other tongue muscles. ${ }^{1}{ }^{2}$ Complete failure of tongue protrusion may occur after bilateral simultaneous cortical or hypoglossal nerve lesions or tandem ipsilateral peripheral (hypoglossal nerve) and central (cortical) lesions. ${ }^{1}$

We postulate that acute cortical infarction with previous infarction of the corresponding contralateral territory 6 months beforehand caused our patient's isolated tongue protrusion palsy.

\section{Learning points}

- Bilateral contraction of genioglossus causes the tongue to protrude in the midline and unilateral contraction causes deviation to the opposite side.

- The genioglossus muscle has contralateral cortical innervation whereas the remaining tongue muscles are bilaterally innervated.

- Unilateral precentral gyrus (motor cortex) cortical infarction may cause tongue deviation away from the side of a lesion. Complete failure of tongue protrusion may occur with bilateral peripheral (hypoglossal) or cortical lesions affecting the precentral gyrus or tandem ipsilateral peripheral and central lesions.
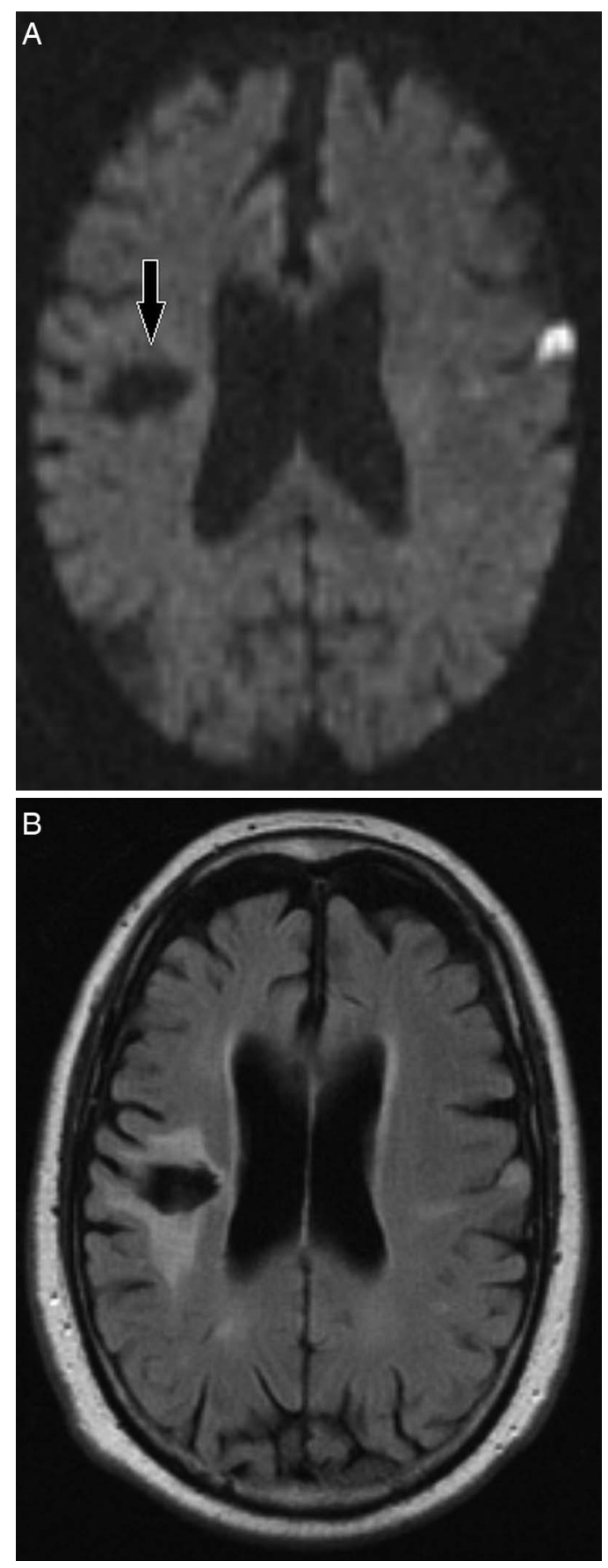

Figure 1 (A) Diffusion-weighted MRI showing small acute left frontal lobe precentral gyrus infarction with previous contralateral infarct evident (black arrow). (B) T2-flair imaging showing signal change in same regions.

Competing interests None.

Patient consent Obtained.

Provenance and peer review Not commissioned; externally peer reviewed. 


\section{REFERENCES}

1 Mouradian MS, Chan KM, Jeerakathil T, et al. Transient total tongue paralysis from simultaneous central and peripheral lesions. J Neurol Neurosurg Psychiatry 2001;70:806-8.
2 Yoon SS, Park KC. Glossoplegia in a small cortical infarction. I Neurol Neurosurg Psychiatry 2007;78:1372.

Copyright 2015 BMJ Publishing Group. All rights reserved. For permission to reuse any of this content visit http://group.bmj.com/group/rights-licensing/permissions.

BMJ Case Report Fellows may re-use this article for personal use and teaching without any further permission.

Become a Fellow of BMJ Case Reports today and you can:

- Submit as many cases as you like

- Enjoy fast sympathetic peer review and rapid publication of accepted articles

- Access all the published articles

- Re-use any of the published material for personal use and teaching without further permission

For information on Institutional Fellowships contact consortiasales@bmjgroup.com

Visit casereports.bmj.com for more articles like this and to become a Fellow 